\title{
Current Trends in Media Research
}

\author{
Juha Herkman
}

In today's era of extensive specialisation researchers tend to know little about other approaches than that of their own expertise. Conceptions of research fields are often based more on personal and common assumptions than knowledge produced by empirical analyses. This article tries to clarify the empirical reality of media research by summarising the results of the project 'Mapping Media and Communication Research', which examined the contents and trends of current media and communication research in seven countries: Finland, the United States, Germany, France, Japan, Estonia and Australia. The project was funded by the Helsingin Sanomat Foundation and carried out by the Communication Research Centre (CRC, University of Helsinki) during a nine-month period between autumn 2006 and spring 2007. ${ }^{1}$ The purpose of the project was to produce an overview of media-related research, in connection with the launch of the Foundation, but at the same time it offered a rare opportunity to outline the similarities and differences among academic approaches in the abovementioned countries.

The project's main research questions were the following:

1. What kinds of media and communication research are carried out in each specific country and who is doing the research?

2. How do different approaches relate to each other?

3. What is the relationship between research and the media industries?

4. In which direction is research headed in the future?

The focus of the project was on media research, but the researchers also took into account studies in speech communication, organisational communication, public relations, research and development of communication technology as well as the economics of communication insofar as these subjects were related to media research. The project not only mapped academic media and communication research but also, insofar as possible, research by governmental institutions, private agencies and media companies. The findings were based on data concerning years 2005-2006, by and large, although a few of the sub-projects have sample data from a longer period and also a more historical perspective on the changes and continuities in media and communication research in a target country (e.g., Germany, France and Japan). The gathering and analysis of the data were carried out during autumn 2006 and spring 2007.

The project team agreed on the research questions, the research principles and the structure of reports in advance in order to enhance meaningful comparison among the countries. Thus, the basic questions and methods behind each country report are the same. The most important part of each subproject was the interview study of key persons in media and communication research. In all, 186 experts were interviewed (see Table 1). Only the German sub-project was based mainly on analysis of written sources (Koivisto \& Thomas 2007, 5).

The interviews produced data, not only facts about media and communication research in each country, but also evaluations and visions of the state and future of such research. The project team members together decided on the organisation, themes and questions for the interviews. In all, the data of the project consists of secondary data from previous studies and existing statistics and primary data from interviews with key persons in media and communication research as well as some statistical analyses made by the country teams themselves.

At first glance the task of mapping the current state of media and communication research in large countries such as the U.S., Japan, France and Germany looked like 'a mission impossible'. It is clear 
Table 1. Experts Interviewed for 'Mapping Media and Communication Research'

\begin{tabular}{lcrrrrrrr} 
& Finland & Estonia & Germany & France & U.S. & Japan & Australia & N = \\
\hline All & 32 & 22 & 12 & 19 & 40 & 37 & 24 & 186 \\
Academy & 16 & 9 & 11 & 16 & 35 & 14 & 18 & 119 \\
Other & 16 & 13 & 1 & 3 & 5 & 23 & 6 & 67 \\
Men & 20 & 13 & 7 & 12 & 31 & 30 & 19 & 132 \\
Women & 12 & 9 & 5 & 7 & 9 & 7 & 5 & 54 \\
\hline
\end{tabular}

that this kind of short-term project cannot reveal allinclusive or complete knowledge of an issue as complex as media and communication research in any country. Even the definitions of the key concepts of 'media research' and 'communication research' vary in different contexts which, in turn, has a multitude of effects on research institutions and disciplines in the countries studied. Thus, each country creates a unique context for media and communication research. Furthermore, the national media statistics as well as the statistical analyses used as a background in country-specific sub-projects are often based on data and methods that are not directly comparable to each other.

As a result, this article will not provide statistically comparable knowledge about media and communication research in the target countries. Moreover, it may not be possible to make broad conclusions from the qualitative comparisons between the countries. The goal of the article is simply to provide a general overview of the current media and communication research in the countries studied and to compare the countries descriptively rather than analytically. The comparison here is based mainly on the country-specific sub-reports of 'Mapping Media and Communication Research', but in contextualising the project, the article also draws upon other references. ${ }^{2}$

It might be asked why these particular countries were included in the project. The target countries do not constitute any homogenous group, quite the contrary. They are located far from one another, they represent various languages and cultures and in some cases their connections to media and communication research do not appear self evident. The choise of target countries was originally made by the project's sponsor, Helsingin Sanomat Foundation. The Foundation has also funded the same kinds of projects for South Korea and Great Britain. Those projects are being carried out at the University of Jyväskylä, and they are not included in this summary because their results were not yet available at the time of writing this article. The selection of countries indicates the interests of the Foundation, which is no doubt interested in "new innovative media markets' in South Korea and Japan, the 'world's leading media market' - the U.S. - various examples of the 'Old World' (France, Germany, Great Britain), and the relationship of these countries to the 'domestic context' (Finland) and its close neighbour (Estonia).

Variations among the countries also proved to be interesting from the academic point of view. Differences in size, languages, societies, cultures and policies in each country made for an unusual combination and forced the researchers to think about their positions as researchers in a new way. Academic research nowadays is remarkably specialised and researchers tend to know little about approaches other than their own, even in their home country not to speak of approaches in other countries or continents. 'Mapping Media and Communication Research' can therefore help media scholars to locate themselves in the broader context of the whole field of research.

This article adopts the structure used in country-specific reports. Therefore, the four main sections are: 1) The media landscapes, 2) Main research institutions and organisations, 3) Main approaches in media and communication research, and 4) Future challenges to research. In the countryspecific reports each section was considered mainly from a national perspective. In this paper the goal is to clarify the similarities in research traditions in addition to identifying national characteristics. The first section then outlines the contexts - the structures of the media market, media and communication legislation, and media consumption - and indicates where the research in each country is positioned. The second section considers the main academic and non-academic research organisations in each country, and the third section focuses on the contents and trends in media and communication research. These sections are based on data gathered by interviews as well as data from quantitative analyses made either by the research teams or by 
earlier researchers. The fourth section summarises the views of the experts interviewed on the future challenges and developments of media and communication research.

\section{The Media Landscapes}

One task of the project was to map the structures of media landscapes in the target countries. This objective was emphasised especially in the case of Japan because the Japanese context is the most unfamiliar from a European point of view. Because the target countries are remarkably divergent, it was not easy to find dimensions in the various media landscapes that are clearly comparable. Nevertheless, the connections of the media and communication industries to the so-called globalisation process reveals at least three interrelated but possibly contradictory tendencies that link the target countries' media landscapes, namely: 1) changes in media and communication technologies, 2) concentration of media ownership, and 3 ) the ideal of a diverse or pluralistic public sphere.

1) In each target country it has been clear for several years that the diffusion of the Internet, online communication and mobile technology challenges the 'old media' in various ways. First, 'old media' have been digitalised and fused with the Internet and mobile networks, as the digitalisation of television, the increasing number of web-papers and magazines, and the pilots of mobile-TV demonstrate (e.g., Aslama et al. 2007, 27-28, 40-42; Herkman \& Vähämaa 2007, 15-31; Valaskivi 2007, 38-39). Second, technological changes have also re-arranged global and national media markets so that the 'old media' increasingly have to compete with new network communication and ICT industries.

The most immediate pressure has been directed towards print media, which in every target country has lost its strength as a media form and advertising channel. Even though changes have not yet been fatal or devastating, in every target country the press is now searching for ways to maintain its audience and advertising share especially in the competition for younger media consumers. A good example of this is the New York Times Company, which on the one hand is one of the most traditional and recognised U.S newspaper houses, while on the other hand it has successfully invested a great deal in online services. (Aslama et al. 2007, 36-38)

The third change is the technological convergence of broadcasting and telecommunication, which will affect not only media markets or media produc- tion and distribution but also media policies and legislation in the target countries (e.g., Valaskivi 2007, 23-24; Herkman \& Vähämaa 2007, 11-12). Convergence and its consequences for media markets, content and communication policies have been much discussed in many countries since the early 1990s (see Baldwin et al. 1996; Küng et al. 1999; Marsden \& Verhulst 1999; Hassan 2000; Murdock 2000; Iosifidis 2002; Lowe \& Hujanen 2003).

2) Concentration of media ownership was an issue that came up in one way or another in every target country. Most evident was the historical concentration of the press (e.g., Puustinen 2007, 18; Rahkonen 2007, 25-31), but it was clear that crossmedia ownership and conglomerates have also become more and more common in every target country during the past few decades (e.g., Aslama et al. 2007, 22-23; Herkman \& Vähämaa 2007, 15-16; Koivisto \& Thomas 2007, 8). Another tendency has been the globalisation, or at least the internationalisation, of media corporations. This tendency has not only occurred in the homelands of the world's biggest media corporations (e.g., the U.S., Japan, Germany and France), but also in smaller countries and media markets such as Finland and Estonia. For example, the Finnish company SanomaWSOY was the largest media company in the Nordic countries until year 2007 and is also a leading magazine publisher in the Benelux countries as well as in some East European countries. Similarly, the Norwegian firm Schibsted and the Swedish houses of Bonnier and Kinnevik own substantial shares of Estonian newspaper and television markets (SalovaaraMoring \& Kallas 2007, 16, 19). Along with concentration there has simultaneously - and paradoxically - been a tendency towards micro-level and user-generated content production by social networks (e.g., Aslama et al. 2007, 16-17). According to David Hesmondhalgh (2002), this trend has been more general among globalising cultural industries during the late 1990s and early 2000s.

In each country the media market could best be described as an 'oligopoly', in which the market is mostly shared by a few large companies (see Picard 1989, 31-33). In most target countries there was also one media corporation that was remarkably larger than the others and therefore undeniably led the competition. These corporations included, for example, Time Warner in the U.S., Bertelsmann in Germany, Vivendi in France, News Corporation in Australia and SanomaWSOY in Finland. These were the companies that were also more international than their local competitors. Time Warner, News 
Table 2. Some Details on Media Markets of Target Countries in 2004-2005

\begin{tabular}{lccccccc} 
& Finland & Estonia & Germany & France & U.S. & Japan & Australia \\
\hline $\begin{array}{l}\text { Largest media co. } \\
\text { Sanoma- } \\
\text { WSOY }\end{array}$ & $\begin{array}{c}\text { Eesti meedia/ } \\
\text { Schibsted }\end{array}$ & Bertelsmann & Vivendi & Time Warner & Sony Co. & News Co. \\
$\begin{array}{l}\text { Revenue, } \\
\text { in US\$ million }\end{array}$ & C. 2,700 & - & 22,196 & 22,194 & 43,652 & $63,895^{*}$ & 23,859 \\
$\begin{array}{l}\text { TV viewing } \\
\text { (min/day) }\end{array}$ & 169 & 270 & 226 & 207 & 491 & 190 & 187 \\
$\begin{array}{l}\text { Leader in } \\
\text { advertising } \\
\text { share (\%) }\end{array}$ & Papers (55) & Papers (44) & Papers (45) & TV (33) & TV (42) & TV (47) & TV (35) \\
\hline
\end{tabular}

* Total revenue: Sony's media revenue in 2004-2005 was 'only' 6,375 million US\$. The advertising Agencies Dentsu and Hakuhodo have higher net revenues and are larger than the largest 'pure' media company, the newspaper firm Yomiuri Shimbun.

Corporation, Bertelsmann and Vivendi belonged to the ten largest media companies in the world (Joukkoviestimet 2006, 333), while SanomaWSOY, in terms of its net revenue, was the largest media company in the Nordic countries until year 2007, when Swedish Bonnier overhauled it. It is clear that media industries would be even more concentrated without state regulation and legislation that prevents monopolisation and trusts. Among the target countries Estonia had a surprisingly diverse media ownership that must have something to do with the relative youth and small size of the Estonian media market. By contrast the Japanese media market is structured quite differently and in a way that makes it difficult to compare to the other target countries: large advertising agencies in Japan, for example, also have an important role in content production, and these agencies are even bigger players in the media markets than 'traditional' media companies (see Valaskivi 2007, 14, 30).

3) Even though there has been a drastic change towards a market-driven or commercial media landscape in the target countries, there is still a strong argument for the idea of a pluralistic or diverse public sphere as the core of a democratic society. However, strategies to achieve this ideal vary from country to country. For example, the U.S. has from the very beginning relied on commercially-based media competition alongside objectivity as a news standard. It is taken for granted that the less the state regulates media, the better the result for democracy: free news competition guarantees diversity of media content. Thus, public service broadcasting accounts for only two per cent of the American television audience share (Joukkoviestimet 2006, 338).
However, since 9/11 and the Iraq war there has been widespread discussion about the 'dumbing down' and narrowing of U.S. news content (Aslama et al. 2007, 32-34), which suggests that the 'liberal' tradition might have serious problems with increasing news competition and its relationship to social and national interests (cf. Curran 2002). In contrast to the U.S., France has relied on state regulation to guarantee the diversity of the public sphere. In France the public sphere and freedom of expression have been linked to national interests to whose cultural integrity the dominance of the U.S. entertainment industries, for example, is seen as a threat. This kind of 'protectionism' may in turn cause other problems (including for media and communication research) than would a more 'liberal' approach. (Puustinen 2007, 11-12.)

Since the 1990s the dominant question in establishing a diverse and pluralistic public sphere in Europe has been the status of public service broadcasting (PSB). The liberalisation and deregulation of the media has been a growing trend in many European countries, not least because of an EU media policy that has stressed economic values over a civic society, for example, and the expanding markets in telecommunication instead of in other media (KaitatziWhitlock 1996; Jakubowicz 2004). In Finland some 40 per cent of the audience share of public service television has been parallel to that in Germany, France and many other EU countries (Joukkoviestimet 2006, 338), but there has also been constant and lively criticism of PSB's role in the media market in Finland (Herkman \& Vähämaa 2007, 1617). In France the state has interfered in television operation perhaps more than in any other target country represented in the 'Mapping Media and Communication Research' project, thanks to a 
media policy that regulates programming directly by nationality and language (Puustinen 2007, 11-12).

It is interesting that broadcasting in Japan and Australia have close resemblances to the European model with their mixed systems of public service and private commercial networks (Valaskivi 2007, 18; Rahkonen 2007, 22). The influence of the BBC has been important all over the world in initiating public broadcasting in the early twentieth century. Also the problems of Japanese and Australian PSB seem to be similar to Europe's. Japanese public broadcaster NHK has encountered difficulties, owing to credibility problems, political scandals, digitalisation and financing. NHK has a 'renewal program' to reduce the number of employees by ten per cent by the end of 2008. (Valaskivi 2007, 27.) A similar renewal programme has been enforced, for example, in the Finnish public broadcasting company YLE. Meanwhile, in the Australia report Juho Rahkonen emphasises the pressure that liberalisation of media market places on public service broadcasting in general: 'Given the neo-liberal market economy and the keen competition, the legitimacy of non-commercial broadcasting can no longer be taken for granted' (Rahkonen 2007, 22-23).

Estonia presents an interesting exception among the European target countries in its relation to PSB. The 19 per cent channel share of public television in Estonia is remarkably less than in other European target countries or the EU average (Salovaara-Moring \& Kallas 2007, 18-19; Joukkoviestimet 2006, 338). In its strong emphasis on commercial broadcasting Estonia represents a typical post-communist society in the Baltic area, where, since the collapse of Soviet Union and the regaining of independence, media legislation has supported a U.S. style liberal market policy. As Salovaara-Moring and Kallas $(2007,26)$ put it: ' $\ldots$ each Baltic state displays a problem common to Central and Eastern Europe: a failure to fully understand the conditions necessary for the emergence of a well-functioning public service broadcaster'. They continue, that 'a weakness is minority programming, an important and sensitive issue in Estonia and also in Latvia since both countries have large Russian-speaking communities. ... The other major problem for public broadcasting in Estonia is the absence of an independent, predictable, stable, and adequate system of funding' (ibid., 27). The problems of PSB in small countries like Estonia and Finland are therefore basically problems created by limited resources.

As the Estonian example illustrates, there are perhaps more country-specific differences than similarities in societies, cultures, languages, markets and media policies. Table 3 summarises some national characteristics in media landscapes of the countries included in the 'Mapping Media and Communication Research' project.

Television has been, and still is, the most popular medium in every target country: people spend most of their media time watching television (see Table 2). Television has also constructed the most influential medium for publicity. In many countries television has been the leading medium for advertising. But if we estimate the relative status of each medium in relation to media landscapes, we see profound differences among the target countries. For example, Finland and Japan even today are traditional 'newspaper countries' in which circulations of dailies per person are among the top five in the world along with Norway, Sweden and Switzerland (Joukkoviestimet 2006, 335).

Even though circulation of dailies is continuously but slowly decreasing, newspapers are still by far the most popular channel for mass media advertising in Finland: newspapers dominate advertising by 54 per cent of the market share, substantially more than television's share of 19-20 per

Table 3. Some National Characteristics in Media Landscapes (2004-2005)

\begin{tabular}{|c|c|c|c|c|c|c|c|}
\hline & Finland & Estonia & Germany & France & U.S. & Japan & Australia \\
\hline Relatively high & newspaper & $\begin{array}{l}\text { television, } \\
\text { cable-tv }\end{array}$ & television & $\begin{array}{l}\text { cinema, } \\
\text { magazines }\end{array}$ & $\begin{array}{l}\text { television, } \\
\text { cinema }\end{array}$ & $\begin{array}{l}\text { mobile, tv, } \\
\text { newspaper }\end{array}$ & $\begin{array}{l}\text { television, } \\
\text { magazines }\end{array}$ \\
\hline Relatively low & television? & print media & newspaper & $\begin{array}{l}\text { newspaper, } \\
\text { Internet }\end{array}$ & print media & $?$ & newspaper \\
\hline State regulation & deregulation & weak & deregulation & strong & weak & quite high & deregulation \\
\hline $\begin{array}{l}\text { Historical } \\
\text { dimension }\end{array}$ & $\begin{array}{l}\text { small market, } \\
\text { high tech, } \\
\text { Nokia }\end{array}$ & $\begin{array}{l}\text { independent in } \\
\text { 1991, Russian } \\
\text { minority }\end{array}$ & $\begin{array}{l}\text { World War II, } \\
\text { federal republic }\end{array}$ & $\begin{array}{l}\text { strong national } \\
\text { identity, } \\
\text { language }\end{array}$ & $\begin{array}{l}\text { 'world's biggest', } \\
\text { culture } \\
\text { industries }\end{array}$ & $\begin{array}{l}\text { World War II, } \\
\text { high tech, } \\
\text { u-strategy }\end{array}$ & $\begin{array}{l}\text { small and } \\
\text { isolated } \\
\text { market, } \\
\text { conservative }\end{array}$ \\
\hline 'New' media & $\begin{array}{l}\text { falling behind, } \\
\text { digital TV }\end{array}$ & $\begin{array}{l}\text { in frontline, } \\
\text { e-voting }\end{array}$ & $\begin{array}{l}\text { 'new economy' } \\
\text { crisis } 2002\end{array}$ & $\begin{array}{l}\text { coming to } \\
\text { frontline, } \\
\text { Minitel }\end{array}$ & in frontline & $\begin{array}{l}\text { most } \\
\text { developed, } \\
\text { mobile }\end{array}$ & $\begin{array}{l}\text { behind, } \\
\text { going online }\end{array}$ \\
\hline
\end{tabular}


cent, which again is much less than television's average 30 per cent share of mass media advertising in the EU (Herkman \& Vähämaa 2007, 18-20; Joukkoviestimet 2006, 122, 334). In Japan television still dominates media markets both in terms of viewing time and advertising revenue (Valaskivi 2007,27 ), but the very special characteristic of the Japanese media landscape is the incredible boom of mobile communication including the mobile internet, broadcasting, books, online music downloading and even the 'virtual wallet'. Japan is the indisputable leader in mobile content development and approximately two to four years ahead of Europe. (Ibid., 30-32, 38-39.) The status of each medium in such country-specific characterisations is classified in Table 3 as 'relatively high' or 'relatively low'. Japan is actually among the top countries in the world in every media sector, and it is therefore hard to define any medium that would have relatively low status in the Japanese media landscape.

The 'statuses' of media are, of course, linked to historical, social and cultural developments in each country. For example, Japanese success in the mobile market is connected to a post-war policy that has emphasised technological and economic development and led to an information society and ' $\mathrm{u}-\mathrm{Ja}$ pan' (Ubiquitous Japan) strategies as national endeavours (ibid., 10-11, 24). The same kinds of visions or strategies have recently come into the world in all the target countries one way or another, but there are significant differences in the commitment to the development of ICT.

According to interviews in information technology, for example, Australia 'lags behind other developed countries' and 'the digital revolution is just [now] about to hit Australia' (Rahkonen 2007, 17). ${ }^{3}$ The reason for this may well be the isolation of the continent, the relatively small population and the high degree of urbanisation, which in turn have led to a combination of conservative media policy and concentrated media market (ibid., 18-21). Likewise, late assimilation into global information networks in France can be linked to the strong maintenance of national identity through language law and cultural protectionism. By contrast, by developing and retaining its own network communication system 'Minitel', averted the spread of the Internet in France for many years. Later, the French eagerly adopted the Internet while European ICT enthusiasm crystallised at the EU's Lisbon meeting in 2000, and today France is one of the top-countries in European Internet connections. Nevertheless, the cinema still has a unique status in French media culture. (Puustinen 2007, 10-12, 19.)
The German media landscape has been structured by decisions made by the Allies after the Second World War that even now influence the German press and broadcasting which are constricted from taking form as 'total' mass media (see Koivisto \& Thomas 2007, 6). The Federal Republic emphasises the regional press, and therefore 'a specificity of the German media landscape is the relatively undersized role of the supra-regional party press' (ibid., 8 ). Even the public media in Germany is organised by federal structure instead of by centralised model. New media in Germany suffered significantly from the crises of 2002, which ended the hype of the virtual 'New Economy'. Since that time, media industries have paid more attention to the so-called core business. (Ibid., 8-9.)

The crises of the 'new media bubble' and $3 \mathrm{G}$ mobile licenses in Germany also upset the Finnish media landscape at the beginning of the twenty-first century. Before that, Finland has been on the frontline of the 'digital revolution', and the keyword in the media branch was convergence. But more recently, media companies have focused on their traditional trade instead of such things as mergers with the ICT business. However, the influence of Nokia on the national economy is so huge that the ICT branch is an engine of the twenty-first century Finnish media business. In household Internet connections Finland has not been among the world's nor even Europe's top countries (e.g., Joukkoviestimet 2006, 346), but Finland was the first country in the world to move completely to terrestrial digital television, during the year 2007.

The special characteristics of the U.S. media landscape are, of course, its leading role as an entertainment producer in the world and the vastness and diversity of its national media markets. A strong domestic market makes the U.S. media branch quite independent from international influences and also keeps it on the frontline of technological and content development (Aslama et al. 2007, 14-15). The U.S. is still unquestionably 'a television country': 'Although on-line and mobile media have become increasingly important, ... the statistics illustrate the crucial role of television as a medium in the U.S.' (ibid., 15-16). After becoming independent in 1991 Estonia adopted the U.S. model of liberal media markets in many ways. Television also dominates the Estonian media landscape, and cable-TV especially has a relatively strong position there (Salovaara-Moring \& Kallas 2007, 18-22). Rapid social changes and the role of the Russian-speaking minority have been the key questions of Estonian media landscape and policies (ibid., 6, 27). 


\section{Main Research Institutions and Organisations}

The country-specific characteristics in the media landscapes discussed above constitute background for media and communication research in each country. Because the size of the population varies among the target countries, the sizes and structures of the university systems are also quite different. But there are also congruencies in structuring media and communication research in each country studied for 'Mapping Media and Communication Research'.

First, in all countries media and communication research is carried out by universities and other academic institutions such as polytechnical schools as well as by non-academic research institutions and organisations. Non-academic research is done by public and private agencies or by research teams in media companies and funded both publicly and privately. In each country there is a much greater degree of private funding of media and communication research than public funding. This is evident in the broadly business-orientated ICT sector. Basically, organisations doing media and communication research in each country are not after all so different.

Second, in all financing of academic media and communication research the share of humanities and social sciences is marginal compared to that of the natural sciences, communication technological development and business research. As the U.S. report explains it, "compared to other social sciences, communication has traditionally received less funding' in general (Aslama et al. 2007, 72). Hence, humanistic and social media and communication research is not at the core of the academic funding system in any target country.

Third, the discipline of academic media and communication research is undefined in many target countries. Especially in countries with very traditional academic institutions like France and Germany, much of the research is carried out by other disciplines than those specifically called media or communication research. A great deal of humanistic and social scientific media and communication research is done, for example, in sociology, the political sciences, linguistics, psychology and the educational sciences. The roots of media and communication research are found in more traditional academic disciplines such as history, philosophy, sociology, science of law, the study of literature, psychology and political sciences - a fact that still affects methodologies, theories and perspectives in media and communication research.

Table 4 illustrates the size of the academic institutions of media and communication education in each target country. It has to be kept in mind that it is very difficult to obtain comparable data even for the numbers of universities, BA/MA/PhD programmes and professors for a specific discipline. As mentioned, the definition of disciplines and number of subjects included in the disciplines vary from country to country. The subjects may also go by different names.

Another problem is that the bigger the country, the more difficult it is to obtain reliable data about these kinds of numbers: tracing all media and communication programmes in the U.S., for example, is extremely time consuming work, and the numbers of programmes and professors change continuously. Therefore the data in Table 4, especially vis-à-vis the U.S. and Germany, have been culled from various secondary sources, and, in the case of Germany, are from seven to ten years old. Because the number of universities, programmes and professorships of media and communication research has steadily grown in Germany (Koivisto \& Thomas 2007, 2630 ), it is assumed that the German numbers in Table

Table 4. Some Details of Academic Media and Communication Education and Research at the National Level

\begin{tabular}{|c|c|c|c|c|c|c|c|}
\hline & Finland & Estonia & Germany & France & U.S. & Japan & Australia \\
\hline Universities & 13 & 2 & 52 (1997) & 22 & c. 400 & c. 230 & 37 \\
\hline $\begin{array}{l}\text { MA/PhD } \\
\text { programmes }\end{array}$ & 27 & $11 / 1$ & $131(2000)$ & - & $109 / 93^{*}$ & $53 / 39$ & 118 \\
\hline Professors & 42 & 13 & $160(2000)$ & 147 & - & - & - \\
\hline $\begin{array}{l}\text { National } \\
\text { characteristics }\end{array}$ & $\begin{array}{l}\text { Nokia/ITC, } \\
\text { private } \\
\text { funding }\end{array}$ & $\begin{array}{l}\text { new centres } \\
\text { of excellence }\end{array}$ & $\begin{array}{l}\text { formal and } \\
\text { hierarchical } \\
\text { system }\end{array}$ & $\begin{array}{c}\text { state control, } \\
\text { unclear } \\
\text { discipline }\end{array}$ & $\begin{array}{c}\text { hard to } \\
\text { discern, } \\
\text { health comm. }\end{array}$ & $\begin{array}{l}\text { strong private } \\
\text { sector, } \\
\text { research } \\
\text { associations }\end{array}$ & $\begin{array}{c}\text { Non- } \\
\text { hierarchical, } \\
\text { industries vs } \\
\text { academy }\end{array}$ \\
\hline
\end{tabular}

\footnotetext{
* In journalism and mass communication only.
} 
4 are too small. The total numbers of MA and PhD programmes in the U.S. will also be much greater than the numbers in Table 4, which includes only programmes in journalism and mass communication. Presumably, the U.S. is a leader in media and communication education and research in the world. Thus, Table 4 tells more in a general level about the scale of academic media and communication education in target countries than it does about exact figures.

More interesting in Table 4 are the short descriptions of the national characteristics of research organisations and institutions. For example, France and Germany proved to serve quite conservative and constricted academic environments for media and communication research because of their hierarchical and introverted university structures. In Germany the postgraduate qualification process, $\mathrm{Ha}$ bilitation, 'does not encourage scientific originality' (ibid., 18). In France the problem has been the relative youth of discipline and the low status of 'Infocom' (Sciences de l'information et de la communication) in the government controlled system of academic research and disciplines (Puustinen 2007, 26-31). In both countries the identity of media and communication research has been poorly defined, and much of the research has been splintered among various more traditional and established disciplines (Koivisto \& Thomas 2007, 15, 43-44; Puustinen 2007, 30-32).

In 'the new world', academic systems seem to be less hierarchical than in the home countries of the modern European university, and media and communication research in Japan, the U.S. and Australia is in many ways more pragmatically oriented than, for example, in Germany and France. But this does not mean that academic research and media industries are closely linked in these countries either. On the contrary, there seems to be quite a gap between media industries and academic research in every target country. The only exception might be Estonia where recent social changes have encouraged all actors in the field to work together. In a small country like Estonia, humanists and social scientists have to look for collaborative projects if they are to obtain extensive funding for larger research projects. (See Salovaara-Moring \& Kallas 2007, 56-57.)

It is actually quite surprising how separate are the academic humanistic and social scientific media and communication research from media industries in the U.S. and Japan, where communication and media industries have an essential position in structuring whole societies. In Japan the relative modesty of academic media and communication research can partly be explained by the obscurity of the disci- pline, but the main reason is the richness of the research conducted by the industries (Valaskivi 2007, 42). In Japan the role of research associations is also exceptionally strong (ibid.). In countries like Japan and the U.S. where 'media has become a huge business', media-related research is also big business (Aslama et al. 2007, 66), and the role of academic media and communication research has remained marginal from the point of view of the media industries. Social scientists have also positioned themselves to be critical actors in society, thereby increasing the gap between academics and industries. Among the target countries the critical tradition has remained quite strong in the U.S., France and Finland, while also in Japan, Australia and Germany many scholars see their task as constituting a critical counterforce against the economic interests of industry.

The gap between industries and academic research has not encouraged industries to finance humanistic and social scientific research or education. The problem has been sharply criticised by an Australian professor: 'Industry takes the graduates but puts very little back to the journalism academy' (Rahkonen 2007, 56). In Finland, the situation changed after the Helsingin Sanomat Foundation, based in the SanomaWSOY corporation, was established in 2005. The Foundation has become the most prominent sponsor of humanist and social media research in Finland. Helsingin Sanomat Foundation also funded the 'Mapping Media and Communication Research' project. (Herkman \& Vähämaa 2007, 47-51.)

But the difficulties in obtaining funding for academic humanistic or social scientific media and communication research become more evident in comparison with technological or natural scientific research in every target country. For example, whereas the Academy of Finland and private Finnish foundations financed humanistic and social scientific media and communication research with some 7 million euros in 2006, Nokia alone financed its research and development by almost 3.9 billion euros in the very same year (ibid., 45). In many target countries, owing to the strong economic assumptions of ICT, state organised research funds are also nowadays channeled mostly to information technological development by various national research programmes and semi-public foundations. For example, the total research financial by the Academy of Finland in 2006 was approximately 257 million euros. The share of humanistic and social scientific media and communication research was between one and two per cent, with the majority of the funding allocated to technological and bio sciences. 
Meanwhile, the Finnish Funding Agency for Technology and Innovation (TEKES) funds research and development activities undertaken by companies and research organisations registered in Finland. In 2006, TEKES invested 465 million euros in research and development projects in companies, universities and research institutes, but humanistic or social scientific media research had only a very limited role in those projects.

On a national level, then, the funding of humanistic or social scientific media and communication research is quite marginal in every target country and dependent on private funding. Country-specific interests may arise in some approaches, however, because they fit current economic and social conjunctures. A good example is health communication research in the U.S., which does not at all have the difficulties that are discussed above (Aslama et al. 2007, 73, 83-84).

\section{Main Approaches in Media and Communication Research}

Many generalisations made in this paper are based on interviews rather than on statistics, but in defining the main research approaches in target countries the conclusions are based mostly on various statistical analyses found in research publications. The problem is that primary data, methods and the classifications behind these statistics have been so heterogeneous that it is hard to make sophisticated comparisons between countries. Nevertheless it is still possible to give a rough overview of the main approaches in media and communication research.

In most countries the main approaches found in media and communication research can be classified in one of three general categories: 1) those that emphasise political and social questions in relation to media or communication, 2) those that emphasise cultural aspects of media and communication, and 3 ) those that focus on media and communication technology. These three categories could be found in all countries but their ratings and precise definitions vary from country to country (see Table 5). Furthermore, the categories are not exclusive and, in many cases, they overlap. For example, cultural and feminist studies often combine cultural and political aspects with their analyses, and technological research is sometimes linked to social and political analysis as it is in the case of information society research. Thus, definitions here simply mean that some dimension of the research appears to be more prominent than others. It is also necessary to note that 'political' is understood more traditionally here as 'politics' or 'policy' than in representation or audience analyses of cultural or feminist studies, where 'political' often refers to identity politics or construction of micro-level power relations.

In Estonia almost all media and communication research seemed to have some connection with social and political questions because of the rapid changes in society after the collapse of the Soviet Union: 'Media is analysed as part of society and not as a separate unity. The rapidly changing society creates new problems to which the academic community must respond.' (Salovaara-Moring \& Kallas 2007, 63.) Specific social and political themes in Estonia are the Russia-speaking minority and adaptation to the post-communistic era (ibid., 61). It is thus not an overstatement to claim that all academic media and communication research in Estonia has a strong connection to social and political questions. It is notable that some topics that are highly popular in the Nordic countries, such as popular culture, feminist media studies and organisational communication, are dealt with only in the student MA theses but otherwise remain in Estonia unpublished (ibid., 62). A special national character-

Table 5. Main Approaches in Media and Communication Research in 2006

\begin{tabular}{|c|c|c|c|c|c|c|c|}
\hline & Finland & Estonia & Germany & France & U.S. & Japan & Australia \\
\hline $\begin{array}{l}\text { Most popular themes } \\
\text { in academic journals } \\
\text { (or books) }\end{array}$ & $\begin{array}{l}\text { Media and } \\
\text { popular } \\
\text { culture; } \\
\text { Political/ societal; } \\
\text { Journalism } \\
\text { studies }\end{array}$ & $\begin{array}{l}\text { Political/ } \\
\text { societal } \\
\text { I; }\end{array}$ & $\begin{array}{l}\text { Mass media; } \\
\text { Communi- } \\
\text { cation in } \\
\text { general }\end{array}$ & $\begin{array}{l}\text { ICT; Media and } \\
\text { popular culture; } \\
\text { Political/ } \\
\text { societal }\end{array}$ & $\begin{array}{l}\text { Mass media; } \\
\text { ICT; Advetising } \\
\text { and PR* }\end{array}$ & $\begin{array}{l}\text { ICT; Media and } \\
\text { popular culture; } \\
\text { Mass media * }\end{array}$ & $\begin{array}{l}\text { Journalism } \\
\text { and news media; } \\
\text { Communication } \\
\text { studies; } \\
\text { Cultural studies }\end{array}$ \\
\hline $\begin{array}{l}\text { National } \\
\text { characteristics }\end{array}$ & $\begin{array}{l}\text { Feminist } \\
\text { critique, } \\
\text { Cultural } \\
\text { studies }\end{array}$ & $\begin{array}{l}\text { Semiotics, } \\
\text { Ethnicity, } \\
\text { Post- } \\
\text { socialism }\end{array}$ & $\begin{array}{l}\text { Humanities, } \\
\text { Unübersicht- } \\
\text { lickeit, Online }\end{array}$ & $\begin{array}{l}\text { Social con- } \\
\text { structivism, } \\
\text { New technology, } \\
\text { National }\end{array}$ & $\begin{array}{l}\text { Diversity, } \\
\text { MCR, Media } \\
\text { effects }\end{array}$ & $\begin{array}{l}\text { National- } \\
\text { Asian, } \\
\text { Western }\end{array}$ & $\begin{array}{l}\text { Cultural studies, } \\
\text { Political } \\
\text { economy }\end{array}$ \\
\hline
\end{tabular}

* The U.S. and Japan data are based on published books (not articles) and are therefore not directly comparable to other countries. 
istic in Estonia is the influence of the famous Tartu school of semiotics (ibid., 64).

In Finland media and popular culture proved to be the most popular topic in academic theses especially at the MA level (Herkman \& Vähämaa 2007, 57), but a later analysis of academic articles published in English reveals that Finnish scholars emphasise also social and political themes, especially in their postgraduate work. There were also clear differences among Finnish university departments and disciplines: the humanities emphasised media and popular culture, while social science emphasised social and political as well as journalism research (ibid., 57-59). However, it became clear that in Finland, it is possible to speak of 'linguistic' or 'cultural' turns in media and communication research because cultural and feminist studies have also had such a great influence on more socially oriented mass communication research.

Popular culture was also a popular research subject in Japan and Australia. Japan has a strong research tradition into Japanese popular culture and media history (Valaskivi 2007, 72-75), while Australia is world famous in Anglo-American cultural studies (Rahkonen 2007, 58-62). However, in Japan today popular culture studies are often connected to 'new media' phenomena such as anime, digital games and World Wide Web (Valaskivi 2007, 66). Therefore, Japanese academic media and communication research in many cases is highly focused on new information and communication technology as is the research by private organisations. It is worth recalling that the Japanese data here are based solely on books published on media and communication issues and the ranking of approaches might be quite different had the ranking been made by academic articles. Overall, Japanese academic media and communication research is modest compared to the private sector, with strong roots in traditional western mass communication research (ibid., 6769). In Japan technological approaches are very strong, and recently there have been efforts to promote collaboration between academic and private research as well as effects to develop genuinely interdisciplinary projects between technological and social approaches (ibid., 82-83).

The national characteristic of Australian media and communication research is pragmatism (Rahkonen 2007, 57). Another key aspect in Australia is the popularity of the political economy resulting from 'the exceptionally concentrated ownership structure' of Australian media. 'The Australian version of political economy is also known as the "media mates approach".' (Ibid., 60.)
Germany and France have quite different relations to media and popular culture studies. While such approaches are popular in France, the research has been concluded more under the distinctive national traditions rather than under the label of Anglo-American cultural studies. This has meant a more elitist-based and more protectionist attitude vis-à-vis commercial popular culture, and the approach has therefore been highly critical in nature. However, since the 1990s, French media and communication research has opened up to international influences, and a new generation of scholars has emerged with a different relationship to popular culture studies. (Sumiala-Seppänen 2007, 99-101.) Today the point of view of social constructivism dominates French media and communication research, and the fascination with new media technologies has broken through to the extent that it can be classified as the most popular theme in France (Puustinen 2007, 63-69).

Research into new media technology - especially online communication - is steadily becoming more common in Germany as well, even though, the conservative and hierarchical academic system emphasises more traditional approaches such as research into mass communication and media effects (Koivisto \& Thomas 2007, 42-43). German national characteristics include the strikingly high share of humanities - for example, linguistics - among media and communication scholars' orientation (ibid., 3233 ) as well as 'the lack of clarity' (Unübersichtlickeit) in the field (ibid., 15). Koivisto and Thomas argue that the conservatism of universities has led to difficulties inserting cultural studies into a German context, and authors see that multidisciplinary cultural studies could serve as a way out of the culde-sac of the 'deadlocked political constellation of the German university' (ibid., 66-71).

Lack of clear definition could also describe the U.S. media and communication approaches in that the research field is so huge and diverse that it is almost impossible to make any generalisations. However, there are some approaches that are obviously stronger than others in the U.S. Traditional mass communication research (MCR) is still perhaps the most popular approach found in U.S. media and communication research, even though interest in new communication technology - especially the Internet - increases continuously. National characteristics of the U.S. are the continuous popularity of media effects research and the strong emphasis on research into advertising and public relations. (Aslama et al. 2007, 83, 110-111.) It is evident that the remarkable role of commercial media industries 
in the U.S. has led to these kinds of national emphases in media and communication research.

A common feature in every target country is an emphasis on empirical research. The status of empirical research is naturally highest among private research organisations, but academic media and communication research is also mainly based on empirical analyses, even though the academy discusses theoretical questions more than does private, industry-based applied research. Yet solely theoretical investigations seem to be quite marginal in today's academy. According to interviews, the most empirical emphasis among the target countries is found in the U.S. and Australia, while theory has the strongest support in France and Japan, and perhaps in Germany.

In most countries quantitative methods still have the strongest position in empirical analysis, but qualitative methods have increased their popularity since the 1980s and the so-called 'cultural' or 'linguistic turn' (see e.g., Bonnell \& Hunt 1999). Private research organisations still rely on quantitative methods, especially on surveys, yet also in the academy quantitative methods such as laboratory experiments, surveys and content analyses evidently dominate in the U.S., Estonia, Germany and Japan. In France and Finland qualitative methods seem to have an exceptionally strong position in academic media and communication research, but this impression is based on interviews rather than being the result of statistical analyses.

The differences among methodologies and the confrontation between theory and empiricism vary by the disciplines and approaches that dominate the national contexts. Aslama et al. (2007, 138-139) argue that tension between humanistic and social scientific approaches is especially characteristic of the U.S. media and communication research, but it is evident that the same kind of distinctions can be found in most of the target countries. There are clear differences between humanistic media (film and television studies, literature studies, linguistics, art history, etc.) and social scientific media (mass communication research, media sociology, journalism studies) and communication approaches, even though the 'linguistic' or 'cultural turn' and the influences of cultural and feminist studies have perhaps made disciplines more similar than ever before (see e.g., Ferguson \& Golding 1997; Murdock 1997).

The separation of social scientific 'research' and humanistic 'studies' also draws lines between theory and empiricism as well as between quantitative and qualitative methods. It was clear that hu- manistic approaches are more 'cultural' in that they rely on qualitative methods and put more emphasis on theories and concepts of symbolic reality than do social approaches, which are more 'materialist' and have stronger traditions in the use of quantitative methods and the reliance on empirical data about social realities. These differences, however, are ill-defined and by no means all-inclusive. Quite the contrary. It seems that discourse analysis and textual analysis as well as criticism of post-modernism and post-structuralism have today become part of almost all humanistic and social media and communication research in the target countries.

\section{Future Challenges to Research}

Even though there were many differences among the target countries, those scholars interviewed seemed to be strikingly unanimous about the future challenges to academic media and communication research. The challenges can be grouped in five interrelated categories that were crystallised in the U.S. report (Aslama et al. 2007, 121). The same categories can be found in one form or another in every report:

\section{The changing media environment}

2. National vs. international orientation

3. The quality of the research

4. Affirming the institutional status of the discipline

5. Improving relationships between academia and industry

The first challenge is the rapidly changing media environment that has been discussed in more detail in the section 'The media landscapes'. In the Japan report Katja Valaskivi $(2007,79-80)$ summarises the changes with the term 'convergence', which combines technological, economical and cultural dimensions of 'converging media systems' (cf. Murdock 2000; Iosifidis 2002). In particular changes in communication technology and markets have been so rapid that many scholars distrusted the ability of academic research to react fast enough: the academy seems to lag behind in technological, social and economic changes. On the other hand it is possible to ask to what extent academic research should react to rapid changes in the media environment and to what extent its task is to 'slow down' or 'denaturalise' the continuous talk about change and the technological hype? Considerable continuity can also be found in media environments, while the social his- 
tory of the media has demonstrated that changes are not always so 'radical' or 'revolutionary' as they are claimed to be in contemporary discourses (see e.g., Winston 1998; Mattelart 2001; Briggs \& Burke 2002).

The second challenge is linked to the first that deregulation and liberalisation of the media have opened national media markets - at least to some extent - to international or global competition. Concentration of media ownership and mergers of media companies have been one result of this process and have made national media markets more dependent on global media corporations (see Croteau \& Hoynes 2001; Doyle 2002). At the same time academic media and communication research has been quite nation-bound because of its commitment to national languages and cultural boundaries as well as to national media and education policies. Many scholars interviewed saw a contradiction between the emphasis in media research on national perspective and media industries' emphasis on international issues.

According to the France report, cultural protectionism and accentuating French language in university policy is a problem in the internationalisation of French media and communication research (Puustinen 2007, 74-77). The situation is completely different in Finland, for example, where publishing in English is the most important means of achieving merit in the academy. Interviewees, especially in small or isolated countries like Finland, Estonia and Australia, seemed to long for international research collaboration. Again it is possible to ask if ranking by publications in international refereed journals - a habit adopted from natural sciences - is truly the best way to evaluate humanistic or social media and communication research. To what extent should media and communication research be national in, for example, and take part in public debates on media's role in society or the nation state?

The third challenge, guaranteeing high quality of research, is intimately linked to complaints about the poor financing and resources of contemporary academic media and communication research. As shown in the section 'Main research institutions and organisations', humanistic and social scientific media and communication research is not at the core of the academy in any of the target countries. This is not surprise. Since the Second World War, development in all research have emphasised large-scale, institutionalised and bureaucratically applied projects whose goal is economic progress or military success, as McNeill and McNeill demonstrate in their world history The Human Web (2003). Academic humanistic and social scientific media research has become a 'second-class citizen', with short-term financing and employments that do not support substantial research projects, which in turn are essential for renewing the discipline. Today the majority of academic media research is carried out by private funding that emphasises industry-based applied studies instead of so-called basic research. Therefore, the key question in all target countries proved to be how to affirm the conditions for selfcontained academic research.

The fourth challenge, affirming the institutional status of the discipline, is also linked to the previous challenges. It is obvious that the relatively low institutional status goes hand in hand with a low degree of academic financing. Many scholars interviewed believed that strengthening the institutional status of the media and communication discipline in the academy would therefore mean more money for research. But there are also other dimensions to the 'lack of disciplinary clarity'. As the country-specific reports of the 'Mapping Media and Communication Research' project demonstrate, there are profound disagreements in defining media and communication research as an academic discipline. Disagreements are in many cases so fundamental that it really seems to be a 'mission impossible' to define any clear-cut discipline of media and communication research. From this point of view, requirements for the congruency of the field can also be seen as belonging to paradigm battles and a threat against plurality or diversity of research; therefore, many scholars, especially those from humanistic or cultural approaches, were quite happy with the current mixed situation in media and communication research in the academy.

The fifth challenge is to overcome the gap between academic media research and media industries. Many scholars both in the academy and in private organisations voiced the desire for increased cooperation between industry and the academy. Academics were expected to take media industries' practical orientation more seriously, and vice versa, while industries were expected to learn more substantial thinking from the academy instead of purely economy-oriented investigations. Some interviewed truly believed that academic research can help industries to contextualise current changes in the media environment and increase knowhow, for example, about qualitative research methods. Academic researchers thought that they in turn could benefit from industries' huge resources and updated micro-level expertise in media and communication technologies, pro- 
duction and marketing. The problem in developing collaboration between the academy and industry is the critical task of the academy, which was still seen as central by many scholars. The sub-projects showed that it is now trendy to speak, for example, of 'creative industries' among academic institutions (e.g., Rahkonen 2007, 66-67). The key question here is to what extent co-operation between the academy and industry is possible without losing the critical potential of academic research.

\section{Notes}

1. The main work behind this paper has therefore been done by the researchers and research teams of the country-specific sub-projects. For work well done I would like to thank Minna Aslama, Kalle Siira, Ronald Rice and Pekka Aula from the U.S. project; Juho Rahkonen from the Australia project; Inka Salovaara-Moring and Triin Kallas from the Estonia project; Katja Valaskivi from the Japan project; Liina Puustinen and Johanna SumialaSeppänen from the France project; Juha Koivisto and Peter Thomas from the Germany project; and Miika Vähämaa from the Finland project. I worked as the project leader of the 'Mapping Media and Communication Research' as well as a leader of the Finland sub-project. In the U.S. project, Professor Philip Napoli served as an advisor and Katy Pearce as a research assistant; in the France project Aura Lindeberg and Elina Perttula worked as research assistants; in the Japan project Hiromi Tsuji worked as a research assistant with Professor Noboru Sonehara serving as an advisor. In the Australia project the University of Queensland (Professor Jan Servaes and assistant Levi Obifiojor) and in the Japan project the National Institute of Informatics in Tokyo (Professor Sonehara) were the collaborative units. In the U.S. project the University of California and the Donald McGannon Communication Research Center at Fordham University were the main units of collaboration. I would also like to thank all those media research experts who were interviewed in each country. Without them the whole project would have been a mission impossible. For more information about the project, see the Appendix.

2. The research reports of each country have been published on CRC's web site: http://www.valt. helsinki.fi/blogs/crc/en/mapping.htm

Reports can also be downloaded from the Helsingin Sanomat Foundation's web site: http:// www.hssaatio.fi/en/completed_projects.html

3. Scholars interviewed in 'Mapping Media and Communication Research' project disagree, for example, the United Nation's E-government Survey 2008, which values Australia really high in global e-governance. See http://unpan1.un.org/ intradoc/groups/public/documents/UN/UNPAN0 28607.pdf.

\section{References}

Aslama, Minna et al. (2007) Mapping Media and Communication Research in the U.S. Research Reports 2/2007. Helsinki: University of Helsinki, Communication Research Centre, Department of Communication.

Baldwin, Thomas et al. (1996) Convergence. Integrating Media, Information \& Communication. London: Sage.

Bonnell, Victoria E. \& Hunt, Lynn (eds.) (1999) Beyond the Cultural Turn. Berkeley: University of California Press.

Briggs, Asa \& Burke, Peter (2002) A Social History of the Media. From Gutenberg to the Internet. Oxford: Blackwell Publishers.

Croteau, David \& Hoynes, William (2001) The Business of Media. Corporate Media and the Public Interest. London: Pine Forge Press.

Curran, James (2002) Renewing the Radical Tradition, in Curran, James: Media and Power, 127-165. London: Routledge.

Doyle, Gillian (2002) Understanding Media Economics. London: Sage.

Ferguson, Marjorie \& Golding, Peter (eds.) (1997) Cultural Studies in Question. London: Sage.

Hassan, Robert (2000) The Space Economy of Convergence, Convergence: The Journal of Research into New Media Technologies 6(2000): 4 (Winter), 18-35.

Hemondhalgh, David (2002) The Cultural Industries. London: Sage.

Herkman, Juha \& Vähämaa, Miika (2007) Viestintätutkimuksen nykytila Suomessa. Viestinnän laitoksen tutkimusraportteja 1/2007. Helsinki: Helsingin yliopisto, Viestinnän tutkimuskeskus CRC, Viestinnän laitos.

Iosifidis, Petros (2002) Digital Convergence: Challenges for European Regulation, in The Public Javnost 9(2002): 3, 27-48.

Jakubowicz, Karol (2004) A Square Peg in a Round Hole: The EU's Policy on Public Service Broadcasting. In Bondebjerg, Ib \& Golding, Peter (eds.) 2004: European Culture and the Media, 277-301. Bristol: Intellect Books.

Joukkoviestimet 2006 - Finnish Mass Media. Helsinki: Statistics Finland.

Kaitatzi-Whitlock, Sophia (1996) Pluralism and Media Concentration in Europe. Media Policy and In- 
dustrial Policy, European Journal of Communication 11(1996): 4, 453-483.

Koivisto, Juha \& Thomas, Peter (2007) Mapping Communication and Media Research: Germany. Research Reports 6/2007. Helsinki: University of Helsinki, Communication Research Centre, Department of Communication.

Küng, Lucy et al. (1999) Impact of the Digital Revolution on the Media and Communications Industries, The Public Javnost 6(1999):3, 29-48.

Lowe, Gregory Ferrell \& Hujanen, Taisto (eds.) (2003) Broadcasting \& Convergence: New Articulations of the Public Service Remit. Göteborg: Nordicom.

Marsden Christopher T. \& Verhulst, Stefaan G. (eds.) (1999) Convergence in European Digital TV Regulation. London: Blackstone Press Ltd.

Mattelart, Armand (2001) Histoire de la société de l'information. Paris: Decouverte.

McNeill, J.R. \& McNeill, William H. (2003) The Human Web. The Bird's-Eye View of World History. New York: W.W. Norton.

Murdock, Graham (1997) Base Notes: The Conditions of Cultural Practice, in Ferguson, Marjorie \& Golding, Peter (eds.), 86-101.

Murdock, Graham (2000) Digital Futures: European Television in the Age of Convergence, in Wieten, Jan et al. (eds.) (2000) Television Across Europe. A Comparative Introduction, 35-58. London: Sage.
Picard, Robert (1989) Media Economics: Concepts and Issues. Newbury Park/California: Sage.

Puustinen, Liina (2007) Mapping Media and Communication Research: France. Research Reports 5/ 2007. Helsinki: University of Helsinki, Communication Research Centre, Department of Communication.

Rahkonen, Juho (2007) Mapping Media and Communication Research: Australia. Research Reports 7/ 2007. Helsinki: University of Helsinki, Communication Research Centre, Department of Communication.

Salovaara-Moring, Inka \& Kallas, Triin (2007) Mapping Communication and Media Research: Estonia. Research Reports 3/2007. Helsinki: University of Helsinki, Communication Research Centre, Department of Communication.

Sumiala-Seppänen, Johanna (2007) Cultural Studies in France - Receptions and Rejections, in Puustinen, Liina 2007, 97-101.

Valaskivi, Katja (2007) Mapping Media and Cотmunication Research: Japan. Research Reports 4/ 2007. Helsinki: University of Helsinki, Communication Research Centre, Department of Communication.

Winston, Brian (1998) Media Technology and Society. A History: From the Telegraph to the Internet. New York: Routledge. 


\section{Appendix}

\section{Facts about the 'Mapping Media and Communication Research'}

The project's budget was a total of 275,000 euros (for seven countries). There were nine researchers in all plus five research assistants and four team leaders. Together their work was a little less than five researcheryears (60 months). The U.S. sub-project's team, consisting of two team leaders, two researchers, a research assistant and an advisor, was the largest, while the Australian project (one researcher for six months), the Finnish (a project leader and one researcher for five months) and the Estonian (two researchers, together working five months) were the smallest sub-projects.

Table. $\quad$ Employees in 'Mapping Media and Communication Research'

\begin{tabular}{|c|c|c|c|c|c|c|}
\hline & Leaders & Months & Researchers & Months & Assistants & Months \\
\hline Finland & 1 & 2 & 1 & 5 & - & - \\
\hline Estonia & - & & 2 & 5 & - & - \\
\hline Germany & - & & 1 & 9 & 1 & 2 \\
\hline France & 1 & 1 & 1 & 5 & 2 & 2 \\
\hline U.S. & 2 & 2 & 2 & 11 & 1 & 2 \\
\hline Japan & - & & 1 & 6 & 1 & 2 \\
\hline Australia & - & & 1 & 6 & - & - \\
\hline
\end{tabular}

Communication Research Centre CRC at the University of Helsinki is carrying out the same kinds of studies on media and communication research in Belgium, the Netherlands and Russia between autumn 2007 and spring 2008. More sophisticated summaries and meta-analyses of all country-specific sub-projects will be completed by the end of 2008. ${ }^{1}$ The budgets of these projects are total some 150, 000 euros, for which four researchers and three research assistants are working. This paper therefore, gives only a brief summary of the results of the 'Mapping Media and Communication Research' project from autumn 2007. Since autumn 2007 the director of the CRC and head of the projects has been Professor Hannu Nieminen.

\section{Note}

1. The analysis will be done by Juha Koivisto and Peter Thomas, researchers from the German sub-project. 